\title{
Periphytic diatom index for assessing the ecological quality of the Colombian Andean urban wetlands of Bogotá
}

\author{
Denisse Castro-Roa ${ }^{1}$ and Gabriel Pinilla-Agudelo,** \\ ${ }^{1}$ M.Sc., Biology. denisecr@gmail.com \\ 2 Associate Professor, Departamento de Biología, Universidad Nacional de Colombia. \\ * Corresponding author: gapinillaa@unal.edu.co
}

Received: 12/02/2014

Accepted: 21/07/2014

\begin{abstract}
Periphytic diatom index for assessing the ecological quality of the Colombian Andean urban wetlands

Five wetlands in Bogotá (Guaymaral, Jaboque, Juan Amarillo, Santa María del Lago and Tibanica) and one rural wetland (Meridor, Tenjo municipality) were sampled four times during dry, rainy and transitory climatic periods (between 2007 and 2008). Physico-chemical variables were measured and periphyton was sampled to evaluate the diatom community. The pollution value per taxon $(P V T)$ was established for each diatom species and a periphytic diatom index for Bogotá Wetlands $(P D I B W)$ was calculated to evaluate the ecological quality of the wetlands. According to the limnological status thus established, the six wetlands can be classified as follows: Santa María del Lago, Meridor and Jaboque exhibit poor to moderate limnological conditions; Tibanica is in poor condition; Guaymaral has severely impaired to moderate conditions; and Juan Amarillo tends to present permanent severely impaired conditions, which indicates that it is the most polluted wetland. The index proposed was useful to classify the wetlands according to their limnological status, and it adequately represents the ecological quality of the Bogotá wetlands.
\end{abstract}

Key words: Bioindicators, pollution index, impacted wetlands, Colombian Andes, Bacillariophyceae.

\section{RESUMEN}

Índice de diatomeas perifíticas para evaluar la calidad ecológica de humedales urbanos andinos de Bogotá, Colombia

Se muestrearon cinco humedales de Bogotá (Guaymaral, Jaboque, Juan Amarillo, Santa María del Lago y Tibanica) y un humedal rural (Meridor, municipio de Tenjo) cuatro veces durante los periodos climáticos seco, lluvioso y de transición (entre 2007 y 2008). Se midieron las variables fisicoquímicas y se obtuvieron muestras de perifiton para evaluar la comunidad de diatomeas. Se establecieron valores de contaminación para cada especie de diatomeas y se calculó un índice de estado limnológico para valorar la calidad ecológica de los humedales. De acuerdo con el estado limnológico establecido, los seis humedales se pueden clasificar de la siguiente manera: Santa María del Lago, Meridor y Jaboque presentan condiciones limnológicas pobres a moderadas; Tibanica están en condiciones pobres; Guaymaral tiene condiciones malas a moderadas; y Juan Amarillo tiende a presentar malas condiciones permanentemente, lo que indica que es el humedal más contaminado. El índice propuesto fue útil para clasificar los humedales dentro de diferentes condiciones limnológicas y representa adecuadamente la calidad ecológica de los humedales de Bogotá.

Palabras clave: Bioindicadores, índice de contaminación, humedales impactados, Andes de Colombia, Bacillariophyceae.

\section{INTRODUCTION}

The wetlands of Bogotá are ecosystems that are strongly affected by the urban matrix that surrounds them. The extent of these ecosystems has been reduced by $99 \%$ since the beginning of the twentieth century. Today, only 1500 hectares remain of the original 150,000 (Moreno et al., 
2005), with the consequent loss of diversity, hydrological regulation, and water storage. In addition to the significant reduction that has occurred in their area, these ecosystems are affected by domestic and industrial residual water discharges and can therefore be categorised as severely altered systems (Van der Hammen et al., 2008). Any action taken to restore or preserve these wetlands requires adequate knowledge of their structure as well as the proper tools to conduct reliable and accurate assessments and monitoring programs. Bioindicators may prove useful in describing the status and cumulative deterioration of these ecosystems (Oliveira and Cortes, 2006). Therefore, it is necessary to develop specific indices for each community and each type of aquatic environment (Wang et al., 2006). Although some assessment studies have been conducted using bioindicator species in Colombia (invertebrates by Riss et al., 2002 and Roldán, 2003; diatoms by Díaz and Rivera, 2004; plankton, aquatic plants, periphyton and invertebrates by Pinilla, 2010), the development of tools to assess ecological communities has still not been explored in sufficient depth. In part, this is because this approach is more complex than the evaluation of a single biotic component (Vis et al., 1998).

Diatoms have been used frequently as bioindicators because they have some advantages over other groups of organisms. These algae are found in practically all aquatic habitats, they are measurable even when the substrate has dried because their frustules (silica shells) are preserved, and they are also excellent indicators of their environmental conditions (Stoermer and Smol, 2004). Therefore, diatoms have been widely used to detect contamination in aquatic systems. Examples can be found from rivers around the world, such as in Europe (Kwandrans et al., 1998; Gonçalves et al., 2008; Solak and Àcs, 2011), South America (Gómez and Licursi, 2001), North America (Kireta et al., 2012; Lavoie et al., 2012), and in a large number of other lotic systems worldwide. In all cases, the utility of this group of organisms as an ecological quality indicator has been demonstrated. Similar studies have also been conducted in urban wetlands and rivers, such as research undertaken by Walker and Pan (2006) in the United States, Walsh and Wepener (2009) in South Africa, and Bere and Tundisi (2011) in Brazil, all of which have confirmed the intense changes facing diatom communities in environments that are heavily affected by urbanisation. In Colombia, Díaz and Rivera (2004), Ramírez and Plata (2008) and Rivera and Donato (2008) have evaluated the use of diatoms as ecological indicators in Andean lotic systems that are subjected to varying degrees of human intervention. In the wetlands of Bogotá, Arcos and Gómez (2006), Pinilla (2010), and Mejía (2011) have assessed the periphytic diatoms of the Jaboque wetland.

There is an urgent need to generate instruments that help to preserve these threatened ecosystems, and this study is an attempt to develop an index to assess the ecological status of the remaining wetlands of Bogotá using diatoms as bioindicators. Other indices based on diatoms (i.e., generic and saprobic) were attempted in this study, but their results were less precise. The

Table 1. General characteristics of the wetlands selected for the study. Water quality and impairment level based on various authors. Características generales de los humedales seleccionados para el estudio. La calidad del agua y el grado de deterioro se basan en diferentes autores.

\begin{tabular}{|c|c|c|c|c|}
\hline Wetland & Geographical coordinates (WGS 84 system) & Altitude (masl) & Water quality $^{a}$ & Impairment level \\
\hline Guaymaral & N4 48.295 W74 02.513 & 2546 & 3 & $\operatorname{High}^{b}$ \\
\hline Jaboque & N4 42.724 W74 07.949 & 2451 & 2 & $\operatorname{High}^{b}$ \\
\hline Juan Amarillo & N4 44.235 W74 06.781 & 2562 & 3 & $\operatorname{High}^{c}$ \\
\hline Sta. María del Lago & N4 41.664 W74 05.638 & 2570 & 1 & Low $^{b}$ \\
\hline Tibanica & N4 36.144 W74 12.177 & 2567 & 3 & $\operatorname{High}^{b}$ \\
\hline Meridor & N4 50.986 W74 07.474 & 2576 & 1 & Low $^{d}$ \\
\hline
\end{tabular}

Water Quality: $1=50-80 \%$ of water sanitation; 2 = without sanitation; 3 = with sewage discharges. ${ }^{a}=$ Van der Hammen et al., $2008 .{ }^{b}=$ Moreno et al., 2005. ${ }^{c}=$ DAMA \& DAPHNIA, 1995. ${ }^{d}=$ Vásquez et al., 2006. 
proposed index employs the taxonomic species level and incorporates various physico-chemical variables, and it is therefore a highly accurate tool. The method permits the assessment and monitoring of the Bogotá wetlands, which are subject both to the impacts of degradation and to restoration projects.

\section{MATERIALS AND METHODS}

\section{Study area}

Based on previous information (DAMA and DAPHNIA, 1995; Moreno et al., 2005; Vásquez et al., 2006; Van der Hammen et al., 2008) and on a reconnaissance visit to 10 wetlands located within the city of Bogotá, five of these wetlands, showing varying degrees of conservation and deterioration, were selected. These wetlands were, from the lowest to the highest level of contamination (i.e., from lower to higher loads of nutrients, organic matter and other pollutants): Santa María del Lago; Jaboque; Tibanica; Guaymaral; and Juan Amarillo, all of which are surrounded by urban areas (Table 1). Due to the lack of well-preserved wetlands in Bogotá, a relatively less altered wetland located in the nearby rural municipality of Tenjo (Fig. 1) was included for contrast. The Meridor wetland is

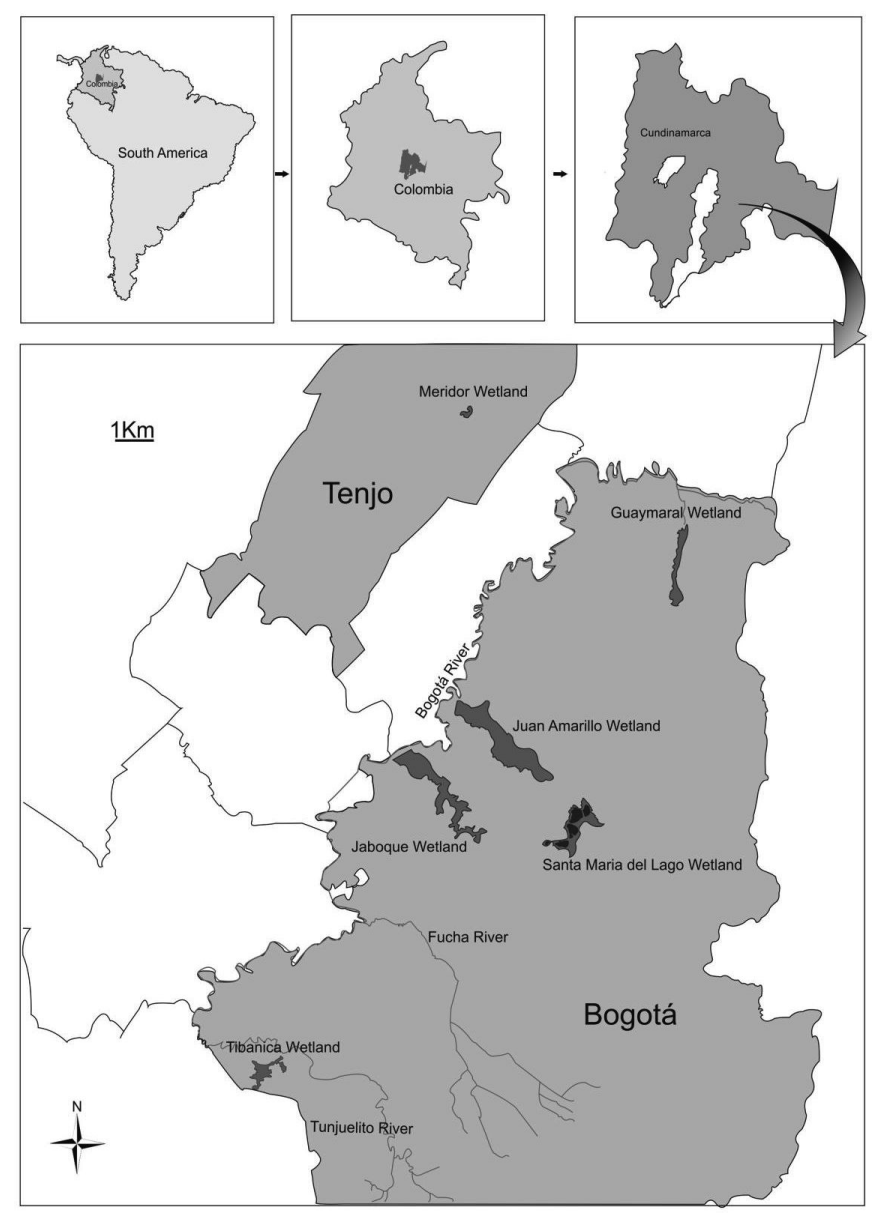

Figure 1. Location map of the wetlands studied in Bogotá. The Meridor wetland in the nearby municipality of Tenjo is also shown. Mapa de localización de los humedales estudiados en Bogotá. También se muestrea el humedal Meridor en la cercana municipalidad de Tenjo. 
comparatively better preserved (Vásquez et al., 2006) and located in the same altitudinal and climatic zone as the Bogotá wetlands (Fig. 1, Table 1). In all these wetlands, sampling was performed in the open water conditions usually found in central zones. The savannah of Bogotá has a mean temperature of $13.5^{\circ} \mathrm{C}$ and an average annual rainfall of between 900 and $1000 \mathrm{~mm}$; there are two rainy seasons (April to June and September to November) and two dry periods (December to February and July to August) (López, 2012). The geology of the plane zone in which the wetlands are located corresponds to quaternary sediments that define lacustrine, fluvial and fluvial-glacial units, deposited in the centre and borders of the basin during the past 3.5 million years (Hooghiemstra, 1984). In these six wetlands (see coordinates in Table 1), sampling was conducted in three climatic periods: the rainy period (November 2007); the dry period (February 2008); and the dry-rainy transitions (March 2008 and August 2008).

\section{Sampling and laboratory methods}

For each wetland, measurements of the following parameters were conducted in situ: water temperature $\left({ }^{\circ} \mathrm{C}\right)$, total dissolved solids $(\mathrm{mg} / \mathrm{l})$, conductivity $(\mu \mathrm{S} / \mathrm{cm})$; and $\mathrm{pH}$ (units), all determined with an ExStik EXTECH EC500 instrument (Extech Instruments Corporation, Nashua, $\mathrm{NH}$ ); dissolved oxygen $(\mathrm{mg} / \mathrm{l})$, determined with an OD600 ExStik EXTECH measure; chlorides $\left(\mathrm{mg} / \mathrm{l} \mathrm{Cl}^{-}\right)$and hardness $\left(\mathrm{mg} / \mathrm{l} \mathrm{CaCO}_{3}\right)$, determined with Merck colorimetric tests (Merck KGaA, Darmstadt, Germany); and transparency $(\mathrm{m})$, determined with a Secchi disk. Additionally, two water samples were collected from the first $40 \mathrm{~cm}$ of the water column: one to carry out a test for biological oxygen demand $\left(\mathrm{mg} / \mathrm{l} \mathrm{BOD}_{5}\right.$ in an incubator at $20^{\circ} \mathrm{C}$ ) and another to measure nitrate concentrations $\left(\mathrm{mg} / \mathrm{l} \mathrm{NO}_{3}^{-}\right)$, nitrite $(\mathrm{mg} / \mathrm{l}$ $\mathrm{NO}_{2}^{-}$), ammonium (mg/l NH $\mathrm{NH}_{4}^{+}$) and orthophosphate $\left(\mathrm{mg} / \mathrm{l} \mathrm{PO} \mathrm{PO}_{4}^{-3}\right)$ with a HACH DR 2000 spectrophotometer (Hach Company, Loveland, $\mathrm{CO})$. Suspended solids $(\mathrm{mg} / \mathrm{l})$ were determined gravimetrically on a $0.0001 \mathrm{~g}$ precision Ohaus scale (Ohaus Corporation, Newark, NJ). All of the chemical analyses followed standard methods (APHA et al., 2012). The collection of periphyton was carried out through scrapings with a modified syringe (Porter et al., 1993) $3 \mathrm{~cm}$ in diameter, covering a total sampling area of $70.6 \mathrm{~cm}^{2}$ in each replicate. Three samples were taken from the most abundant plant found in each wetland (stems or leaves of Schoenoplectus californicus, Eichhornia crassipes or Hydrocotyle ranunculoides, depending on the site) and another three were collected on artificial substrates (plastic films) with three months of colonisation time. The diatom samples from each wetland were mixed and identified as a whole sample. Cleaning was conducted using the oxidation method (Stevenson and Bahls, 1999), and frustules were fixed on permanent mounts with Naphrax resin (Northern Biological Supplies Ltd., Ipswich, UK). Observations were performed using a light microscope at a $100 \times$ magnification, and in some cases, scanning electron microscopy was employed (SEMElectron Microscopy Laboratory, Department of Geosciences at the Universidad Nacional de Colombia). For taxonomic determination, the keys set forth by Rivera et al. (1982), Krammer and Lange-Bertalot $(1986,1991)$ and Lange-Bertalot (1996) were used, as well as the descriptions by Lange-Bertalot and Metzeltin (1998), Lange-Bertalot (2000), and Metzeltin and LangeBertalot (2007). Counts were made until reaching 500 frustules of the most abundant species. Samples were deposited at the Palynology Laboratory of the Institute of Natural Sciences-ICN of the Universidad Nacional de Colombia.

\section{Data analysis}

The diatom taxonomic and abundance results of natural and artificial substrates were merged into a single spreadsheet matrix. A principal components analysis (PCA) of the physico-chemical variables was performed to find the organisational patterns of the wetlands based on their aquatic environment. A canonical correspondence analysis (CCA) was implemented as well, with the purpose of exploring the relationships between the diatom species and the water's phy- 
sico-chemical qualities. This CCA was executed with variables and species that had maximum coefficients of variation. These analyses were performed with PAST software (version 2.17c, Hammer et al., 2001, Natural History Museum, University of Oslo, Norwegian).

To construct the pollution index $(P I)$, the methodology proposed by Jiang and Shen (2003) and Jiang (2006) was followed, which is based on three steps. The first step is to calculate the pollution values of the physico-chemical variables in each wetland (for each climatic period) using the following formula:

$$
P I=\sum_{i=1}^{n} \frac{C}{C L}
$$

Table 2. Averages and standard deviations of the physico-chemical variables measured in the studied wetlands $(n=24)$. The high mineralisation of Meridor is natural and is discussed in the text. Taxonomic nomenclature according to Lange-Bertalot (1996). Promedios y desviaciones estándar de las variables físicas y químicas medidas en los humedales estudiados. La alta mineralización de Meridor es natural y se discute en el texto. La nomenclatura taxonómica según Lange-Bertalot (1996).

\begin{tabular}{|c|c|c|c|c|c|c|}
\hline Parameter & Tibanica & Jaboque & Juan Amarillo & Santa María del Lago & Guaymaral & Meridor \\
\hline \multicolumn{7}{|l|}{ Water Temperature } \\
\hline$\left({ }^{\circ} \mathrm{C}\right)$ & $18.5 \pm 0.93$ & $20.2 \pm 2.21$ & $19.6 \pm 2.38$ & $19.3 \pm 1.45$ & $16.4 \pm 0.54$ & $18.9 \pm 1.27$ \\
\hline \multicolumn{7}{|l|}{ Total Dissolved } \\
\hline Solids (mg/l) & $785.2 \pm 215.5$ & $108.9 \pm 18.6$ & $366.0 \pm 162.1$ & $178.6 \pm 70.0$ & $293.7 \pm 73.6$ & $588.8 \pm 383.1$ \\
\hline $\begin{array}{l}\text { Conductivity } \\
(\mu \text { Siemens/cm) }\end{array}$ & $1351.7 \pm 446.8$ & $166.6 \pm 9.1$ & $539.0 \pm 222.5$ & $240.7 \pm 43.7$ & $423.7 \pm 61.2$ & $1168.3 \pm 232.3$ \\
\hline $\begin{array}{l}\text { Dissolved Oxygen } \\
(\mathrm{mg} / \mathrm{l})\end{array}$ & $1.65 \pm 1.34$ & $9.78 \pm 3.09$ & $2.25 \pm 2.12$ & $5.08 \pm 2.50$ & $2.70 \pm 1.08$ & $5.37 \pm 2.87$ \\
\hline DO Saturation (\%) & $19.7 \pm 15.97$ & $116.58 \pm 36.9$ & $26.8 \pm 25.3$ & $60.6 \pm 29.85$ & $32.25 \pm 12.85$ & $64.13 \pm 34.23$ \\
\hline pH (units) & $6.93 \pm 0.14$ & $9.04 \pm 0.21$ & $7.34 \pm 0.29$ & $7.16 \pm 0.24$ & $7.09 \pm 0.32$ & $7.40 \pm 0.35$ \\
\hline Chloride $\left(\mathrm{mg} / \mathrm{l} \mathrm{Cl}^{-}\right)$ & $83.75 \pm 20.56$ & $19.25 \pm 2.5$ & $32.0 \pm 20.07$ & $19.25 \pm 5.44$ & $46.38 \pm 18.45$ & $356.75 \pm 78.75$ \\
\hline $\begin{array}{l}\text { Hardness } \\
\left.(\mathrm{mg} / \mathrm{l} \mathrm{CaCO})_{3}\right)\end{array}$ & $151.75 \pm 48.23$ & $65.0 \pm 10.89$ & $97.5 \pm 29.76$ & $106.43 \pm 9.32$ & $129.75 \pm 39.63$ & $331.5 \pm 63.14$ \\
\hline $\begin{array}{l}\text { Secchi Transparency } \\
\text { (m) }\end{array}$ & $0.96 \pm 0.4$ & $0.57 \pm 0.29$ & $0.27 \pm 0.24$ & $1.31 \pm 0.23$ & $0.01 \pm 0.0$ & $1.41 \pm 0.76$ \\
\hline $\begin{array}{l}\text { Total Suspended } \\
\text { Solids (mg/l) }\end{array}$ & $29.71 \pm 30.0$ & $34.71 \pm 18.99$ & $52.69 \pm 33.92$ & $0.89 \pm 1.16$ & $269.43 \pm 353.89$ & $28.83 \pm 10.35$ \\
\hline $\begin{array}{l}\text { Nitrate } \\
\left(\mathrm{mg} / 1 \mathrm{NO}_{3}^{-}\right)\end{array}$ & $0.59 \pm 1.14$ & $0.75 \pm 1.11$ & $0.83 \pm 1.38$ & $0.49 \pm 0.94$ & $0.59 \pm 1.14$ & $1.24 \pm 1.55$ \\
\hline $\begin{array}{l}\text { Nitrite } \\
(\mathrm{mg} / \mathrm{l} \mathrm{NO}-)\end{array}$ & $0.002 \pm 0.002$ & $0.08 \pm 0.15$ & $1.76 \pm 3.49$ & $0.25 \pm 0.5$ & $0.009 \pm 0.014$ & $0.03 \pm 0.05$ \\
\hline $\begin{array}{l}\text { Ammonium } \\
\left(\mathrm{mg} / \mathrm{NH}_{4}^{+}\right)\end{array}$ & $1.03 \pm 0.48$ & $0.79 \pm 0.41$ & $16.09 \pm 12.23$ & $0.47 \pm 0.17$ & $0.82 \pm 0.31$ & $1.02 \pm 1.62$ \\
\hline $\begin{array}{l}\text { Orthophosphate } \\
\left(\mathrm{mg} / \mathrm{l} \mathrm{PO}_{4}^{-3}\right)\end{array}$ & $0.68 \pm 0.54$ & $0.62 \pm 0.54$ & $3.32 \pm 4.4$ & $0.46 \pm 0.77$ & $0.64 \pm 0.56$ & $0.48 \pm 0.72$ \\
\hline Biological Oxygen & & & & & & \\
\hline Demand $\left(\mathrm{mg} / \mathrm{l} \mathrm{O}_{2}\right)$ & $19.5 \pm 12.77$ & $20.0 \pm 3.37$ & $78.75 \pm 51.53$ & $26.5 \pm 29.44$ & $66.25 \pm 88.27$ & $21.75 \pm 18.23$ \\
\hline
\end{tabular}


where $C$ is the measured value of the variable in the wetland, and $C L$ is the limiting value of this variable based on Decree 1594 of the Colombian legislation (Ministry of Agriculture, 1984). The variables used in this calculation were conductivity, total dissolved solids, dissolved oxygen, $\mathrm{pH}$, chloride, carbonate hardness, ammonium, nitrites, nitrates, phosphates and $\mathrm{BOD}_{5}$. The sum of the $P I$ values for each of the physicochemical variables provides an individual $P I$ for each wetland, which can vary according to the climatic period.

Then, the pollution value for each taxon $(P V T)$ was calculated as a combination of all the seasonal data. This seasonal aggregation allows for a comprehensive and global response of the taxon. The formula is:

$$
P V T=\frac{\sum_{i=1}^{n}\left(\frac{\ln 10 P I}{n}\right) i}{N}
$$

where $n$ is the number of measured physicochemical variables, ln is the natural logarithm, $P I$ is the value calculated above, $N$ is the number of sites, and $i$ represents the presence of each species in each particular place. The $P V T$ is unique for each species and depends on its presence in the wetlands and on the examined physico-chemical characteristics. To select the upper (very tolerant species) and lower (most sensitive species) $P V T$ limits, we used the deciles technique; we selected the first and ninth decile as the low and high range, respectively. Tolerant taxa have a higher $P V T$ value, and sensitive ones have lower $P V T$ values.

The third step was to calculate the pollution value for the periphytic diatom community (Periphytic Diatom Index for Bogotá Wetlands$P D I B W)$ of each wetland in each period according to the following formula:

$$
P D I B W=\frac{\sum_{i=1}^{n}(P V T) i}{n_{s}}
$$

where $n_{s}$ is the number of species, $P V T$ is the value calculated (as above) for each species, and $i$ represents the occurrence of the species in each particular place. This value is an indicator of the degree of pollution in each wetland for the corresponding climatic period.

To better interpret the PDIBW obtained for the diatom communities, a percentage transformation was conducted in which $100 \%$ corresponded to the highest value of the $P D I B W$ among the sites. This result was subtracted from 100 to obtain a score directly proportional to the state of conservation (the higher PDIBW value corresponds to the better limnological state). Following the indications set forth in Pinilla (2010), the quartile technique was used, and four categories were established for the PDIBW values.

\section{RESULTS}

The values of the measured physico-chemical variables for the studied wetlands are reported in Table 2. The PCA (Fig. 2) distinguishes among the six wetlands according to their physicochemical characteristics. The variance explained by components 1 and 2 was $26.3 \%$ and $17.2 \%$, respectively. Component 1 is related with a nutrients gradient, and Juan Amarillo (JU) and Guaymaral (GU) are located in the high range of this axis, especially the samples taken in the dry and transitional periods. Meridor (ME) and Santa María (SM) are at the opposite extreme with fewer nutrients. Juan Amarillo showed an elevated concentration of orthophosphates, ammonium and nitrite but also high organic matter loads (represented by $\mathrm{BOD}_{5}$ ), as did Guaymaral. Component 2 has a mineralisation significance based on the conductivity and chloride scores; Tibanica (TB) and Meridor are in the higher values of this gradient, and Jaboque (JA) and Santa María had less mineralised and more oxygenated and transparent waters. The hypoxic conditions at Tibanica, Juan Amarillo and Guaymaral were noteworthy (oxygen saturation below 35\%). The $\mathrm{pH}$ levels were close to neutral in all of the ecosystems except Jaboque, which was under alkaline conditions.

Secchi transparency, total suspended solids and nutrients varied greatly among the rainy, dry and transitional seasons. Although each wetland 
behaved in a particular way, some similarity of physico-chemical conditions according to the climatic epochs was evident. During the rainy period, phosphate tended to increase, most likely because it was transported from the surroundings into the wetlands. Nitrate was augmented during transition stages, perhaps due to nitrification processes within the wetlands. The $\mathrm{BOD}_{5}$ also tended to increase in the rainy periods, possibly as a response to higher organic matter transported by runoff.

$P V T$ values were calculated for the 153 taxa collected in the six studied wetlands during the four climatic periods. Of these taxa, only those identified with the species level or belonging to genera represented by a single taxon are listed in Table 3. Many taxa could not be clearly identified because the taxonomy of Colombian diatom flora is poorly known, and so a further investment is required to clarify the species composition. It should be noted that $P V T$ values range from 2 to 4.6. This range is moderately narrow, and this obeys the logarithmic conversion in the equation proposed by Jiang and Shen (2003) and Jiang (2006). In subsequent studies, it could be interesting to work without this transformation.

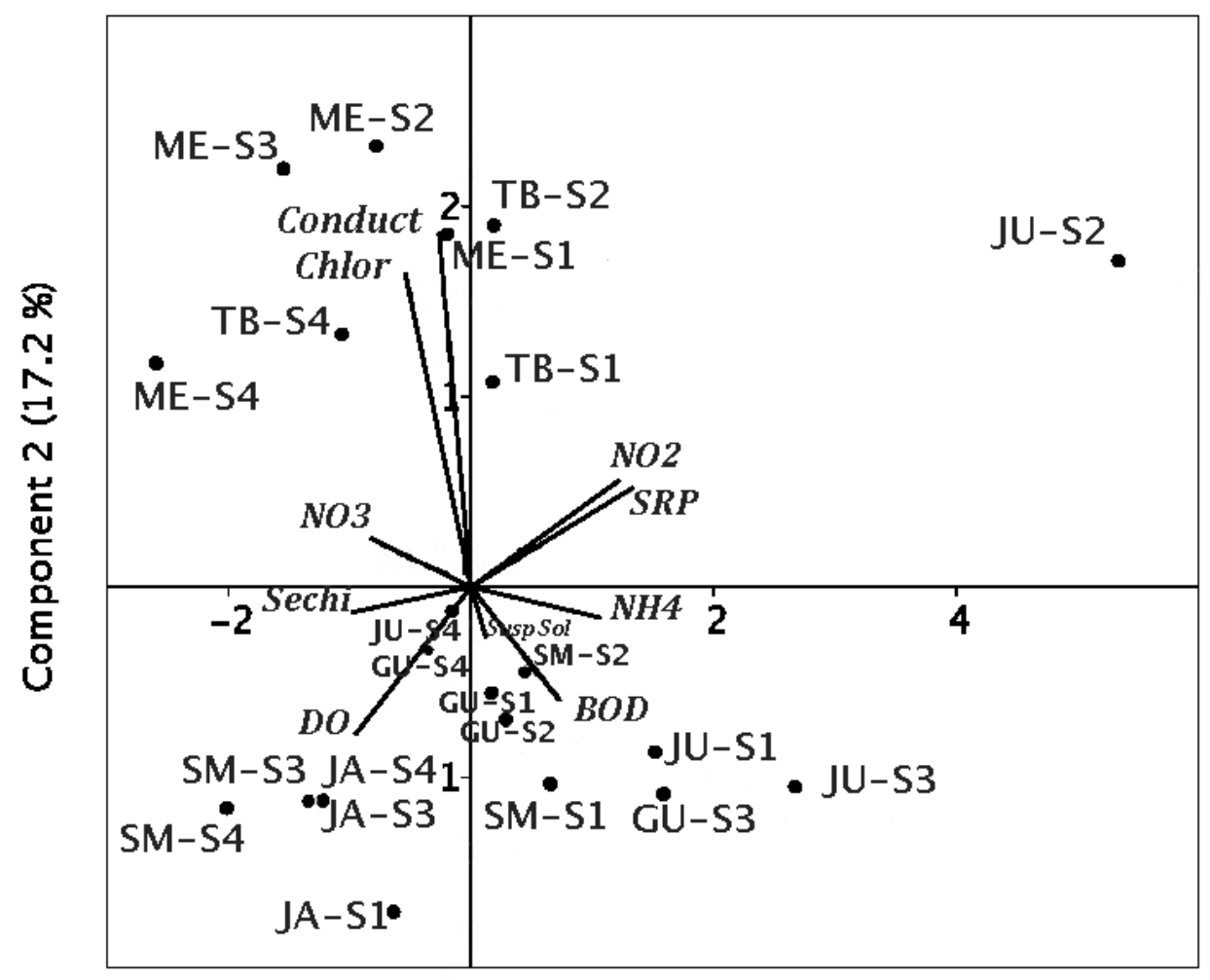

\section{Component 1 (26.3\%)}

Figure 2. Biplot of the Principal Components Analysis for the physico-chemical data of the Bogotá wetlands. TB = Tibanica. JA = Jaboque. JU = Juan Amarillo. SM = Santa María del Lago. GU = Guaymaral. ME = Meridor. S1 = rainy period sampling. S2 = dry period sampling. S3 = March dry-rainy transition sampling. S4 = August dry-rainy transition sampling. DO = dissolved oxygen. $\mathrm{BOD}=$ biological oxygen demand. $\mathrm{SRP}=$ soluble reactive phosphorus. $\mathrm{NH} 4=$ ammonium $. \mathrm{NO} 2=$ nitrite $. \mathrm{NO} 3=$ nitrate $. \mathrm{Conduc}=$ conductivity. Chlor $=$ chloride. Susp_Sol = suspended solids. Secchi = Secchi transparency. Análisis de Componentes Principales de los datos físicos y químicos de los humedales de Bogotá. TB = Tibanica. JA = Jaboque. JU = Juan Amarillo. SM=Santa María del Lago. $G U=$ Guaymaral. $M E=$ Meridor. $S 1=$ muestreo del periodo lluvioso. $S 2=$ muestreo del periodo seco. $S 3=$ muestreo de la transición sequía-lluvias de Marzo. S4 = muestreo de la transición sequía-lluvias de Agosto. DO = oxígeno disuelto. BOD = demanda biológica de oxígeno. $S R P=$ fósforo reactivo soluble. $H N 4=$ amonio. NO2 = nitrito. $N O 3=$ nitrato. Conduc $=$ conductividad . Chlor = cloruro. Sups_Sol = sólidos suspendidos. Secchi = transparencia Secchi . 
Table 3. Pollution values for the taxa $(P V T)$ of periphytic diatoms in the wetlands of Bogotá. Only diatoms classified to the species level and monospecific genera were included. Higher values correspond to species that are more tolerant to pollution. Abbreviations of the selected species for the CCA are included. Valores de polución de los taxones (PVT) de diatomeas perifiticas en los humedales de Bogotá. Solo se incluyen las diatomeas clasificadas hasta el nivel de especie y los géneros monoespecíficos. Los valores más altos corresponden a las especies que son más tolerantes a la contaminación. Se incluyen las abreviaturas de las especies seleccionadas para el CCA.

\begin{tabular}{|c|c|c|c|c|c|}
\hline Species & Acronym & PVT & Species & Acronym & PVT \\
\hline Achnanthes exigua & Ach_ex & 3.291 & Gomphonema truncatum & Gom_tr & 3.111 \\
\hline Achnanthidium minutissimum & & 3.287 & Gomphonema vibrio var intricatum & & 3.215 \\
\hline Anomoeoneis cf sphaerophora var sculpta & Ano_sc & 3.434 & Grunowia solgensis & Gru_si & 3.0 \\
\hline Aulacoseira granulata & Aul_gr & 3.15 & Gyrosigma cf nodiferum & & 2.005 \\
\hline cf Bacillaria sp & & 3.215 & Halamphora coffeaeformis & Hal_co & 3.289 \\
\hline Caloneis sp & & 3.836 & Halamphora cf montana & Hal_mo & 3.327 \\
\hline Cocconeis placentula & Coc_pl & 3.266 & Hantzschia amphioxys & Han_am & 3.553 \\
\hline Cocconeis placentula var euglypta & Coc_eu & 2.988 & Lemnicola hungarica & & 3.392 \\
\hline Craticula ambigua & Cra_am & 3.367 & Melosira varians & & 4.515 \\
\hline Cyclotella meduanae & Cyc_me & 3.239 & Navicula cf arvensis & Nav_ar & 3.903 \\
\hline Cyclotella meneghiniana & & 3.259 & Navicula cf leptostriata & Nav-le & 2.846 \\
\hline Cyclotella cf ocellata & & 2.502 & Navicula recens & Nav_re & 3.186 \\
\hline Cyclotella stelligera & Cyc_st & 3.398 & Navicula cf tantula & & 3.165 \\
\hline Cymbella cf gracilis & & 2.787 & Nitzschia amphibia & Nit_am & 3.079 \\
\hline Cymbella lanceolata & Cym_la & 3.004 & Nitzschia capitellata & Nit_ca & 3.823 \\
\hline Cymbella tumida & & 3.754 & Nitzschia inconspicua & Nit_in & 3.415 \\
\hline Cymbopleura naviculiformis & Cym_na & 2.246 & Nitzschia pusilla & & 4.648 \\
\hline cf Diadesmis sp & & 2.005 & Nitzschia reversa & & 2.981 \\
\hline Encyonema minutum & & 4.648 & cf Nitzschia sigmoidea & & 4.525 \\
\hline Encyonema cf silesiacum & Enc_si & 3.121 & Pinnularia acutobrebissonii & Pin_ac & 3.241 \\
\hline Eolimna cf subminuscula & Eol_su & 3.264 & Pinnularia gibba & Pin_gi & 4.253 \\
\hline Ephitemia adnata & & 3.027 & Pinnularia cf lundii & Pin_lu & 3.762 \\
\hline Epithemia cf sorex & & 3.16 & Pinnularia maior & Pin_ma & 3.606 \\
\hline Eunotia bilunaris & Eun_bi & 3.159 & Pinnularia microstauron & & 3.3 \\
\hline cf Eunotia subarcuatoides & & 2.621 & Pinnularia cf subcapitata & Pin_su & 3.305 \\
\hline Eunotia tridentula & & 4.515 & Pinnularia viridiformis & Pin_vi & 3.448 \\
\hline cf Kobayasiella sp & & 3.438 & Planothidium lanceolatum & Pla-la & 2.769 \\
\hline Fragilaria acus & Fra_ac & 3.287 & Rhoicosphenia sp & & 4.648 \\
\hline Frustulia rhomboides & Fru_rh & 3.903 & Rhopalodia gibba & Rho_gi & 2.9 \\
\hline Frustulia saxonica & Fru_sa & 2.822 & Sellaphora aff rectangularis & & 3.158 \\
\hline Gomphonema acuminatum & & 3.009 & Sellaphora pupula & & 3.096 \\
\hline Gomphonema affine & Gom_af & 3.026 & Sellaphora $\mathrm{sp}$ & Sella & 3.121 \\
\hline Gomphonema angustatum & Gom_an & 3.299 & Stauroneis sp & Stau & 3.288 \\
\hline Gomphonema cf augur & & 2.502 & Staurosira mercedes & Sta_me & 3.268 \\
\hline Gomphonema cf clavatum & & 3.158 & Staurosirella leptostauron & Sta_le & 3.381 \\
\hline Gomphonema gracile & & 3.348 & Staurosirella pinnata & Sta_pi & 3.553 \\
\hline Gomphonema cf olivaceum & Gom_ol & 3.199 & Surirella cf brebissonii & Sur_br & 2.644 \\
\hline Gomphonema parvulum & & 3.18 & Tabellaria sp & & 2.787 \\
\hline Gomphonema pseudoaugur & Gom_ps & 3.343 & Ulnaria ulna & Uln_ul & 3.171 \\
\hline Gomphonema punae & Gom_pu & 2.879 & & & \\
\hline
\end{tabular}


Table 4. Classification scale according to the PDIBW for the wetlands evaluated. Escala de clasificación de los humedales evaluados de acuerdo al PDIBW.

\begin{tabular}{ccc}
\hline PDIBW $(\%)$ & Interpretation & Implications \\
\hline$>38$ & Slightly contaminated & Wetland with good or acceptable limnological conditions \\
$36-38$ & Moderately contaminated & Wetland with moderate or intermediate limnological conditions \\
$33-36$ & Highly contaminated & Wetland with poor or deficient limnological conditions \\
$<33$ & Severely contaminated & Wetland with bad or severely impaired limnological conditions \\
\hline
\end{tabular}

Based on the PDIBW data as transformed to percentages, a scale was constructed that allowed for the classification of the limnological status of each wetland (Table 4). The categorisation of the wetlands for each climatic period based on this scale can be observed in figure 3 , and a general classification of their limnological status is shown in Table 5. Figure 3 reveals that the most deteriorated wetland is Juan Amarillo, which exhibited challenging limnological conditions in all climatic periods sampled, and consequently was catalogued as a severely contaminated environment. At the other extreme, Santa María del Lago and Meridor exhibited a superior limnological state. During the transition seasons (March and August, 2008), Santa María showed good limnological conditions, indicating a low level of pollution, but for rainy and dry periods (November 2007, February 2008), its limnological conditions were deficient, corresponding to high levels of contamination. Meridor fluctuated between high pollution (poor limnological state) in rainy and dry-rainy transition periods and slight pollution (acceptable limnological conditions) in the dry period.

At Jaboque, the limnological conditions were poor for three climatic periods, but during the March dry-rainy sampling, a moderate state was observed. Guaymaral presented considerable variation in ecological quality, which shifted from a bad limnological state (severe pollution in the March dry-rainy transition period) to an intermediate state (moderate pollution in periods of rain and drought). In the August transition period, this wetland exhibited poor limnological conditions (high pollution). Meanwhile, Tibanica presented poor limnological conditions throughout the study period, indicating high contamination. However, the index values for this ecosystem showed a gradual tendency of improvement of its limnological conditions (Fig. 3).

The CCA (Fig. 4) showed an interesting association between some diatom taxa and the physico-chemical environment of the wetlands. Axis 1 explained $26.8 \%$ of the variance, and axis 2 explained $17.4 \%$ of the variance. The first axis represents a mineralisation gradient with Meridor and Tibanica located to the left due to their high conductivity and chloride content. Species such as Fragilaria acus, Gomphonema affine, Eunotia bilunaris, Ulnaria ulna, Cocconeis placentula, Eolimna cf subminuscula, Anomoeoneis cf sculpta and Navicula recens were associated with these highly mineralised wetlands; the $P V T$ values for all these taxa ranged between 3.07 and 3.43. Axis 2 is less clearly related to saprobic conditions (top), water transparency and oxygenation (bottom). Most of the samples from Jaboque, Juan Amarillo and Guaymaral are located in the top section of the graph, i.e., they are more polluted wetlands with high registers of $\mathrm{BOD}_{5}$, ammonium and suspended solids. Representative taxa of this cluster are several species of Pinnularia (P. gibba, P. cf subcapitata, P. maior, $P$. cf lundii, $P$. acutobrebissonii), Frustulia rhomboides, Staurosira mercedes, Staurosirella pinnata, Staurosirella leptostauron, Surirella cf brebissonii, Hantzschia amphioxys, Gomphonema punae, Gomphonema pseudoaugur, Navicula cf arvensis, and Cymbella lanceolata, among others. The $P V T$ values of these diatoms vary between 2.64 and 4.25 . The ecological significance of axis 2 (in its lower section) is linked to more transparent and oxygenated wetlands (Santa María and Jaboque), where the characteristic diatom species were Grunowia solgensis, Planothidium lanceolatum, Aulacoseira granulata, Cyclotella stelligera, Gomphonema cf oli- 


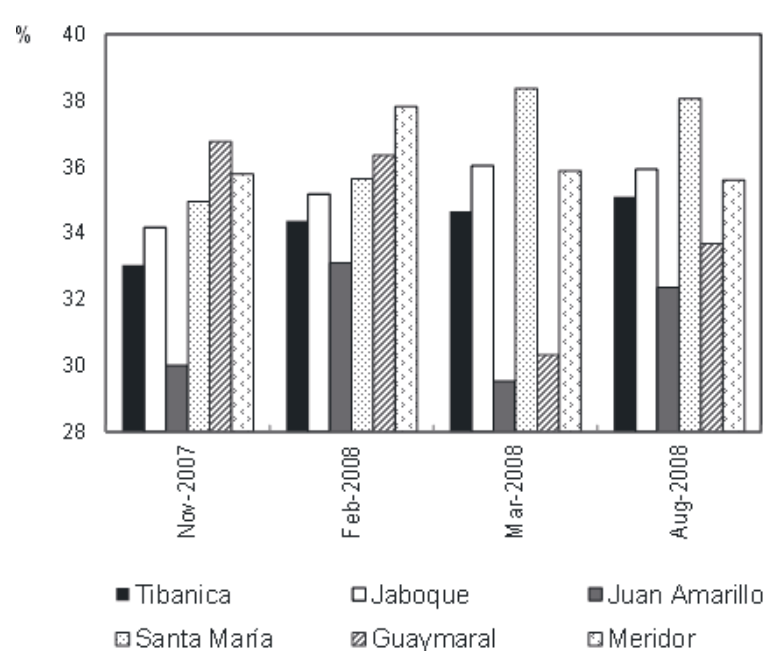

Figure 3. $P D I B W$ scores as percentages for the investigated wetlands in each period evaluated. Puntajes en porcentaje del PDIBW para los humedales investigados en cada periodo evaluado.

vaceum, Craticula ambigua, Frustulia saxonica, Encyonema cf silesiacum, Navicula cf leptostriata, Rhopalodia gibba, Halamphora cf montana, Achnanthes exigua, and Cymbopleura naviculiformis. The PVT values in this group fluctuated between 2.76 and 3.39 .

\section{DISCUSSION}

The physico-chemical variables assessed indicate that Juan Amarillo presented the most eutrophic (higher nutrient levels) and the most saprobic conditions (most organic matter), indicating that it is the most polluted system. Tibanica and Guaymaral also showed a high degree of pollution, mainly due to an elevated level of dissolved ions (the maximum permissible level under Decree 1594 is $500 \mathrm{mg} / \mathrm{l}$ ) and low oxygen concentration. Meridor had elevated mineralisation too, but with oxygenated waters. The least altered wetlands from a physico-chemical standpoint were Jaboque and Santa María del Lago. Meridor can also be considered an ecosystem with minor contamination, despite its elevated grade of mineralisation (high conductivity, hardness, chlorides and dissolved solids). This mineralisation has a geological origin in local deposits of rocks that are rich in salts in the Tabio region where this wetland is located (Pinilla, 2010). Thus, its high conductivity is natural and not caused by human activities. The alkaline $\mathrm{pH}$ at Jaboque is a result of high primary production, which is reflected in its elevated concentration of chlorophyll (Malagón, 2008); this fact implies a high consumption of $\mathrm{CO}_{2}$ and consequent increases in carbonates in the water.

Almost all of the wetlands exceeded the maximum permissible values (Decree 1594) for ammonium $(1 \mathrm{mg} / \mathrm{l})$ and orthophosphates $(0.2 \mathrm{mg} / \mathrm{l})$. Additionally, Juan Amarillo and Santa María del Lago surpassed the maximum acceptable concentration for nitrite $(0.1 \mathrm{mg} / \mathrm{l})$, whereas none of the wetlands exceeded the acceptable levels of nitrate $(10 \mathrm{mg} / \mathrm{l})$. Wetlands are environments that are commonly enriched in nutrients, and they frequently have large quantities of organic matter because they maintain high primary production and accumulate large

Table 5. General classification for the wetlands studied according to the PDIBW. Clasificación general de los humedales estudiados de acuerdo al PDIBW.

\begin{tabular}{|c|c|c|c|c|}
\hline Wetland & Mean PDIBW & Standard Deviation & Range of Precision of the PDIBW & Interpretation Based on Diatoms \\
\hline Tibanica & 34.29 & 0.88 & $33.41-35.17$ & Poor limnological conditions \\
\hline Meridor & 36.51 & 0.93 & $35.58-37.44$ & $\begin{array}{l}\text { Poor to moderate limnological } \\
\text { conditions }\end{array}$ \\
\hline Jaboque & 35.33 & 0.85 & $34.48-36.18$ & $\begin{array}{c}\text { Poor to moderate limnological } \\
\text { conditions }\end{array}$ \\
\hline Juan Amarillo & 31.24 & 1.74 & 29.5-32.98 & $\begin{array}{l}\text { Severely impaired limnological } \\
\text { conditions }\end{array}$ \\
\hline Santa María & 36.74 & 1.71 & $35.03-36.74$ & $\begin{array}{l}\text { Poor to moderate limnological } \\
\text { conditions }\end{array}$ \\
\hline Guaymaral & 34.27 & 2.97 & $31.3-37.24$ & $\begin{array}{l}\text { Severely impaired to moderate } \\
\text { limnological conditions }\end{array}$ \\
\hline
\end{tabular}


amounts of biological material (Westlake et al., 1998). However, the excess nutrients and organic matter loads are mainly due to pollution of the wetlands in Bogotá.

Among the diatoms that constitute the periphytic communities in the wetlands of Bogotá, several species stand out owing to the high pollution values obtained ( $P V T$ greater than 3.9, corresponding to the ninth decile), such as Frustulia rhomboides, Navicula cf arvensis, Nitzschia sigmoidea, Eunotia tridentula, Melosira varians, Nitzschia pusilla, Pinnularia gibba, Encyonema minutum and Rhoicosphenia $\mathrm{sp}$. These species appear to be associated with high loads of organic matter and nutrients in the water, which is why $P$. gibba, N. arvensis, and F. rhomboides were associated with Jaboque, Juan Amarillo and Guaymaral wetlands in the CCA analysis (Fig. 4). These taxa are very cosmopolitan (Kelly et al., 2005; Lane and Brown, 2007) and are usually highly tolerant to eutrophication and extremely saprobic conditions. Melosira varians, for example, has been reported with an elevated saprobic value in the Brazilian Rio Pardo Hydrographical Basin (Lobo et al., 2010). Bere and Tundisi (2011) also noted that some species of the genera Nitzschia and Pinnularia were typical of sites with very poor

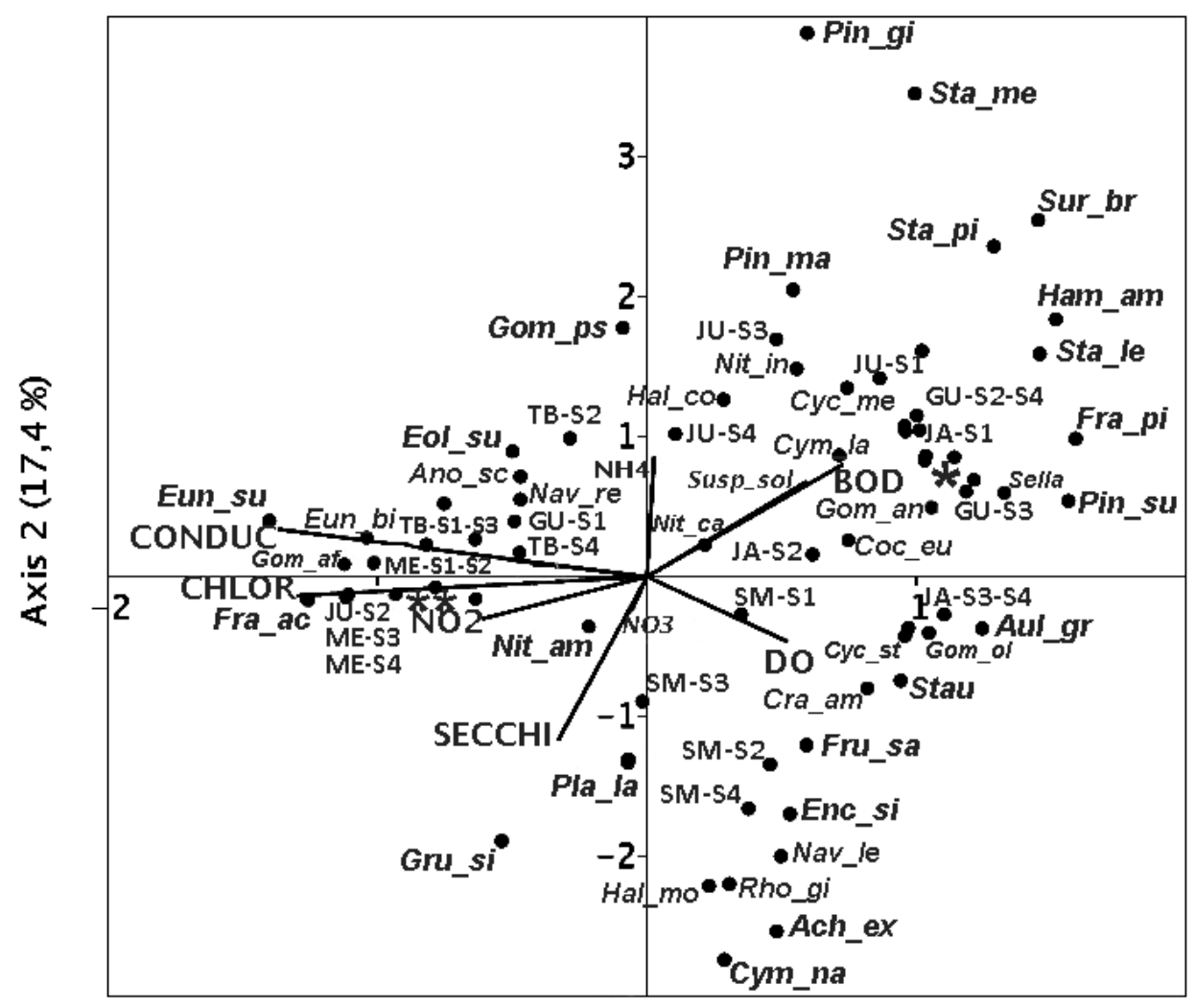

Axis $1(26,8 \%)$

Figure 4. Triplot of the canonical correspondence analysis for the diatoms taxa and physico-chemical variables of the Bogotá wetlands. Around *: Fru_rh, Gom_ps, Gom_pu, Nav_ar, Pin_ac, Pin_lu, Pin_vi. Around **:Coc_pl, Gom_tr, Uln_ul. Abbreviations as in Figure 2. Species acronyms are listed in Table 3. Análisis de Correspondencia Canónica para los taxones de diatomeas y las variables físicas y químicas de los humedales de Bogotá. Alrededor de *: Fru_rh, Gom_pu, Nav_ar, Pin_ac, Pin_lu, Pin_vi. Alrededor de **: Coc_pl, Gom_tr, Uln_ul. Las abreviaturas son las mismas de la Figura 2. Los acrónimos de las especies se listan en la Tabla 3. 
water quality. In contrast, the species with the lowest PVT values (less than or equal to 2.8, which corresponds to the first decile, such as Eunotia subarcuatoides, Surirella cf brebissonii, Planothidium lanceolatum, Cymbella cf gracilis, Tabellaria sp., Diadesmis sp, Cyclotella cf ocellata, Cymbopleura naviculiformis, Gomphonema cf augur, and Gyrosigma cf nodiferum) appear to be sensitive to highly contaminated conditions and prefer mesotrophic environments. Within this group, the CCA analysis related P. lanceolatum and $C$. naviculiformis to less polluted wetlands (Santa María and Jaboque). Likewise, some taxa of these genera (Eunotia and Cymbella) have also been identified to be indicators of less contaminated waters (Kwandrans et al., 1998; Salomoni et al., 2006), and P. lanceolatum was designated as a mesosaprobic species by Kelly et al. (2005). As reference values, it should be noted that the theoretical $P V T$ for any species (computed by taking into account the best and worst possible values of the physico-chemical variables used in the estimation of the $P I$ ), could vary between 0.6 and 5.2 for clean and heavily polluted water, respectively. In general, the assignations of sensitivity and tolerance to pollution for the species observed in the present study are similar to those found in other investigations of diatoms as bioindicators, such as those of Lobo et al. (2002) and Kelly et al. (2005). This suggests that the methodology used in this study to assign the $P V T$ is appropriate and consistent.

At the genus level, there is a tendency for some of these taxa to be tolerant to contamination, but others are more sensitive. The more tolerant genera include Nitzschia and Pinnularia, and the more sensitive were Cymbella and Gomphonema. However, the diatom bioindicators systems that are most widely employed internationally use the species level, due to the wide range of tolerance to pollution (organic matter and nutrients) found within genera. This is especially true for taxa from the genera Navicula, Nitzschia, Achnanthes and Gomphonema, which contain species ranging from extremely sensitive to quite tolerant (Lobo et al., 2002; Lobo et al., 2004; Salomoni et al., 2006; Lobo et al., 2010). Nevertheless, there are some approaches that employ diatom genera (Kwandrans et al., 1998; $\mathrm{Wu}$ and Kow, 2002; Solak and Àcs, 2011) and show some degree of certainty regarding the determination of water pollution, although the results are typically less precise than when the species level is used.

The results obtained using the PDIBW allowed for the classification of the wetlands into different limnological categories, ranging from moderately to heavily polluted. At Santa María del Lago, the PDIBW revealed fairly good limnological conditions, related to a lower level of contamination. It is evident that the physico-chemical attributes of wetlands directly affect the structure of the associated diatom community, which can be detected relatively easily through changes in the taxonomic composition (Wang et al., 2006). Many studies have established that diatoms are mainly sensitive to changes in physico-chemical variables such as conductivity, $\mathrm{pH}, \mathrm{BOD}_{5}$, and dissolved oxygen (Fore and Grafe, 2002; Lobo et al., 2004; Walker and Pan, 2006; Bere and Tundisi, 2011) but especially to those parameters associated with nutrients and organic matter loads in the system. These elements appear to be particularly strong determinants for the diatoms in inland aquatic environments (Lobo et al., 2002; Wang et al., 2006; Lane and Brown, 2007).

It is important to note that in the interpretation of limnological status based on the PDIBW, not only the mean value of the index must be considered but also the range of variation, which can be established from the standard deviation (Table 5). As a result, we have a more realistic view of the oscillations in ecological conditions that occur in wetlands. Similarly, calculation of the PDIBW for each climatic period reveals variations in the wetlands' ecological quality, possibly due to changes in inputs of nutrients and organic matter and fluctuations in other physico-chemical variables, such as dissolved oxygen, water transparency and dissolved solids. Ammonium and $\mathrm{BOD}_{5}$ were parameters that showed a wide range of variability, and the highest concentrations were found at Juan Amarillo and Guaymaral, particularly in the third period, which contained the lowest values for the PDIBW 
found in this phase. Thus, the PDIBW can be a useful tool to assess temporal changes in these aquatic systems.

The present evaluation of the Bogotá wetlands using the $P D I B W$ is consistent in some aspects with the ecological status recorded in the literature for these ecosystems, although this correspondence is not complete. For example, according to the previous assessments of physical and biological characteristics carried out in Tibanica, this wetland was considered to present the poorest status amongst those evaluated by Van der Hammen et al. (2008) and Pinilla (2010), and it is therefore thought to have some of the most deteriorated conditions among all of the wetlands in the city of Bogotá. However, in this study, Tibanica presented intermediate conditions as its $P D I B W$ score was slightly above that of Guaymaral, which ranked second worst in terms of limnological conditions.

As stated by the PDIBW, Juan Amarillo was the most deteriorated wetland, but in other studies, its categorisation has been less severe (Mejía, 2006; Van der Hammen et al., 2008). This may be because those studies took into account aspects that are more related to the physical characteristics of the system (e.g., hydrology, morphology and some chemical parameters), which appear to assign different limnological conditions to these wetlands. The characterisations outlined in those studies seem less reliable for establishing the actual state of ecological quality. The limnological categorisation obtained with the PDIBW could provide a good ecological indicator because it assesses the integrity of the whole system, which means that diatoms incorporate the protracted effects on the system on a short or median temporal scale. Given that diatoms respond rapidly to physico-chemical changes, it is possible that the effects of subsequent actions aimed at controlling or improving the conditions of the wetlands may be quickly detected. Similarly, the PDIBW differences between rainy and dry seasons should be a good indicator of the changes over time.

Based on field observations, we were able to establish that one of the critical problems at Guaymaral was the reduction of the open water surface, which reduces the ecological functions of planktonic and periphytic communities. It is expected that in shallow areas (less than $20 \mathrm{~cm}$ ), conditions become more critical for sensitive organisms such as diatoms (higher temperature, photoinhibition). Similarly, from the beginning of the study, a progressive loss of open water areas at Juan Amarillo was observed. It was caused by the advance of Eichhornia crassipes, which is a plant that benefits from highly eutrophic environments (Cronk and Fennessy, 2001). Therefore, in these two wetlands, the conditions for the development of diatoms were unfavourable.

On the other hand, the PDIBW scores corroborate the conclusion that the ecological quality is better at Santa María del Lago. The physical characteristics of this wetland are appropriate, and there is an adequate supply of nutrients for the establishment of biotic communities according to the Van der Hammen et al. (2008) study. Among the studied Bogotá wetlands, Santa María del Lago presents the best conditions, both limnological and sanitary. This may indicate that the measures undertaken for the restoration and conservation of this wetland more than 12 years ago (López, 2012) have been appropriate and may serve as a model for achieving these goals in other wetlands in the city. For Jaboque, the PDIBW also showed that ecological quality could vary between deficient and intermediate.

In summary, we conclude that the PDIBW performed well as a tool for the evaluation of the limnological conditions in the Bogotá wetlands. Despite the lack of abundant data in its calculations, the new index was able to provide good results based only on taxonomic composition and physico-chemical variables. Nevertheless, a good bioindicator system should be applicable to extensive geographic areas and the greatest possible number of ecological environments (Jorgensen et al., 2005). The PDIBW proposed in this study represents an initial approximation and must be strengthened with a greater number of samples in light of the similar degradation values of the six studied wetlands. Therefore, the validation of the $P D I B W$ using data from other urban wetlands is required, preferably with information from other similar environments in the savannah of Bogotá 
or in the Colombian Andean high plateau. To broaden the index's ability to detect degradation and allow for the assessment of the ecological quality of a wider group of Andean wetlands, a larger set of data is recommended, preferably one including systems with broadly contrasting limnological conditions and some pristine sites.

\section{ACKNOWLEDGEMENTS}

This project was funded by the Research Division of the Universidad Nacional de Colombia (DIB code 8003168) and was carried out within the framework of the LCIWB project (Limnological Conditions Index for Wetlands of BogotáICOL-Índice de Condiciones Limnológicas para los Humedales de Bogotá), in which Sandra Rojas, Manuela Venegas, Andrés Malagón and Oscar Jiménez also participated by assisting in various phases of this study. The authors also thank the Biology Postgraduate Program of the Department of Biology at the Universidad Nacional de Colombia for academic and logistical support, Orlando Rangel, Director of the Palynology Laboratory of the Institute of Natural Sciences ICN, where the laboratory phase of the study was conducted, and the non-governmental administrative foundations of each wetland. We also thank the reviewers for their valuable contributions.

\section{REFERENCES}

AMERICAN PUBLIC HEALTH ASSOCIATION (APHA), AMERICAN WATER WORKS ASSOCIATION (AWWA) \& WATER POLLUTION CONTROL FEDERATION (WPCF). 2012. Standard methods for the examination of water and wastewater, $22^{\text {nd }}$ ed. APHA, Washington.

ARCOS, M. P. \& A. C. GÓMEZ. 2006. Microalgas perifíticas como indicadoras del estado de las aguas de un humedal urbano: Jaboque, Bogotá D.C. Nova-Publicación Científica, 4: 60-79.

BERE, T. \& J. G. TUNDISI. 2011. Influence of landuse patterns on benthic diatom communities and water quality in the tropical Monjolinho hydrological basin, São Carlos-SP, Brazil. Water South Africa, 37: 93-102.
CRONK, J. \& M. FENNESSY. 2001. Wetland plants, biology and ecology. Lewis,Boca Raton, USA.

DEPARTAMENTO TÉCNICO ADMINISTRATIVO DEL MEDIO AMBIENTE (DAMA) \& DAPHNIA LTDA. 1995. Estudio ecológico y diseño del plan de manejo ambiental del humedal Juan Amarillo-Santafé de Bogotá D.C. (Informe Técnico). Alcaldía Mayor de Santafé Bogotá, Bogotá, Colombia.

DÍAZ, C. \& C. RIVERA. 2004. Diatomeas de pequeños ríos andinos y su utilización como indicadoras de condiciones ambientales. Caldasia, 26: 381-394.

FORE, L. \& C. GRAFE. 2002. Using diatoms to assess the biological condition of large rivers in Idaho (U.S.A.). Freshwater Biology, 47: 20152037.

GÓMEZ, N. \& M. LICURSI. 2001. The Pampean Diatom Index (IDP) for assessment of rivers and streams in Argentina. Aquatic Ecology, 35: 173181.

GONÇALVES, V., P. RAPOSEIRO \& C. COSTA. 2008. Benthic diatoms and macroinvertebrates in the assessment of the ecological status of Azorean streams. Limnetica, 27(2): 317-328.

HAMMER, Ø., D. A. HARPER \& P. D. RYAN. 2001. PAST: Paleontological statistics software package for education and data analysis. Retrieved from Palaeontologica Electronica, 4: 9: http://palaeoelectronica.org/2001_1/past/past.pdf

HOOGHIEMSTRA, H. 1984. Vegetational and climatic history of the high plain of Bogota, Colombia: a continuous record of the last 3.5 million years. Dissertationes Botanicae, 79, 1-368. J. Cramer Verlag, Vaduz.

JIANG, J. 2006. Development of a new biotic index to assess freshwater pollution. Environmental Pollution, 139: 306-317.

JIANG, J. \& Y. SHEN. 2003. Development of a biotic index using the correlation of protozoan communities with chemical water quality. New Zealand Journal of Marine and Freshwater Research, 37: 777-792.

JORGENSEN, S., R. CONSTANZA \& F. XU. 2005. Handbook of ecological indicators for assessment of ecosystem health. CRC Press, Boca Raton, USA.

KELLY, M. G., H. BENNION, E. J. COX, Y. GOLDSMITH, J. JAMIESON, S. JUGGINS, D. G. MANN \& R. J. TELFORD. 2005. Common freshwater diatoms of Britain and Ireland: an interactive 
key (electronic publication). Retrieved from the Environment Agency, Bristol, England, United Kingdom: http://craticula.ncl.ac.uk/EADiatomKey/ html/index.html.

KIRETA, A. R., E. D. REAVIE, G. V. SGRO, T. R. ANGRADI, D. W. BOLGRIEN, B. H. HILL \& T. M. JICHA. 2012. Planktonic and periphytic diatoms as indicators of stress on great rivers of the United States: Testing water quality and disturbance models. Ecological Indicators, 13: 222-231.

KRAMMER, K. \& H. LANGE-BERTALOT. 1986. Süßwasserflora von Mitteleuropa. Bacillariophyceae, teil 1: Naviculaceae. Gustav Ficher, Jena, Germany.

KRAMMER, K., H. LANGE-BERTALOT. 1991. Süßwasserflora von Mitteleuropa. 3 teil: Centrals, Fragilariceae, Eunotiaceae. Gustav Fisher, Stuttgart, Germany.

KWANDRANS, J., P. ELORANTA, B. KAWECKA \& K. WOJTAN.1998. Use of benthic diatom communities to evaluate water quality in rivers of southern Poland. Journal of Applied Phycology, 10: 193-201.

LANE, C. R. \& M. T. BROWN. 2007. Diatoms as indicators of isolated herbaceous wetland condition in Florida, USA. Ecological Indicators, 7: 521540.

LANGE-BERTALOT, H. (ed.) 1996. Iconographia diatomologica. Volume 4. Taxonomy. Koeltz Scientific Books, Königstein, Germany.

LANGE-BERTALOT, H. (ed). 2000. Iconographia diatomologica. Volume 9. Diatoms of the Andes. Koeltz Scientific Books, Königstein, Germany.

LANGE-BERTALOT, H. \& D. METZELTIN. 1998. Iconographia Diatomologica. Volume 5. Tropical Diatoms of South America I: About 700 predominantly rarely known or new taxa representative of the neotropical flora. Koeltz Scientific Books, Königstein, Germany.

LAVOIE, I., M. LAVOIE \& C. FORTIN. 2012. A mine of information: Benthic algal communities as biomonitors of metal contamination from abandoned tailings. Science of the Total Environment, 425: 231-241.

LOBO, E. A., V. L. CALLEGARO \& E. P. BENDER. 2002. Utilização de algas diatomáceas epilíticas como indicadoras da qualidade d água em rios e arroios da região hidrográfica do Guaíba, RS, Brasil. Universidade do Santa Cruz do Sul, Santa Cruz do Sul, Brasil.
LOBO, E. A., V. L. CALLEGARO, G. HERMANY, D. BES, C.E. WETZEL \& M. A. OLIVEIRA. 2004. Use of epilithic diatoms as bioindicator from lotic systems in southern Brazil, with special emphasis on eutrophication. Acta Limnologica Brasiliensis, 16: 25-40.

LOBO, E. A., C. E. WETZEL, L. ECTOR, K. KATOH, S. BLANCO \& S. MAYAMA. 2010. Response of epilithic diatom communities to environmental gradients in subtropical temperate Brazilian rivers. Limnetica, 29(2): 323-340.

LÓPEZ, R. H. 2012. Estado trófico de un humedal urbano andino tropical: Santa María del Lago, Bogotá D.C. Colombia. Universidad Militar Nueva Granada, Bogotá, Colombia.

MALAGÓN, A. 2008. Descripción del estado trófico de cuatro humedales de la Sabana de Bogotá, a partir de la composición, biomasa y producción del fitoplancton. Undergraduate Thesis, Universidad Nacional de Colombia, Bogotá, Colombia.

MEJÍA, A. P. 2006. Estudio evaluativo descriptivo de los humedales Juan Amarillo, Córdoba y Jaboque como mitigadores del cambio climático y planteamiento de una estrategia de fortalecimiento para este potencial (Bogotá-Colombia). Undergraduate Thesis, Pontificia Universidad Javeriana, Bogotá, Colombia.

MEJÍA, D. M. 2011. Diatomeas perifíticas y algunas características limnológicas de un humedal urbano en la sabana de Bogotá. Master's Thesis, Universidad Nacional de Colombia, Bogotá, Colombia.

METZELTIN, D. \& H. LANGE-BERTALOT, H. 2007. Iconographia diatomologica. Volume 18. Tropical diatoms of South America II: Special remarks on biogeographic disjunction. Koeltz Scientific Books, Königstein, Germany.

MINISTERIO DE AGRICULTURA (REPÚBLICA DE COLOMBIA). 1984. Decreto 1594 por el cual se reglamentan los usos del agua y residuos líquidos. Diario Oficial No 36.700, Bogotá, Colombia.

MORENO, V., J. F. GARCÍA \& J. C. VILLALBA. 2005. Descripción general de los humedales de Bogotá, D.C. Retrieved from the Sociedad Geográfica de Colombia, Bogotá, Colombia: http://www. sogeocol.edu.co/documentos/humed.pdf.

OLIVEIRA, S. V. \& R. M. CORTES. 2006. Environmental indicators of ecological integrity and their development for running waters in northern Portugal. Limnetica, 25: 479-498. 
PINILLA, G. 2010. An index of limnological conditions for urban wetlands of Bogotá city, Colombia. Ecological Indicators, 10: 848-856.

PORTER, S. D., T. F. CUFFNEY, M.E. GURTZ \& M. R. MEADOR. 1993. Methods for collecting algal samples as part of the national water quality assessment program. Retrieved from the U.S. Geological Survey, Open-File Report 93-409, USA: http://water.usgs.gov/nawqa/protocols/OFR-93409/alg1.html.

RAMÍREZ, A. M. \& Y. PLATA. 2008. Diatomeas perifíticas en diferentes tramos de dos sistemas lóticos de alta montaña (páramo de Santurbán, Norte de Santander, Colombia) y su relación con las variables ambientales. Acta Biológica Colombiana, 13: 199-216.

RISS, W., R. OSPINA \& J. D. GUTIÉRREZ. 2002. Establecimiento de los valores de bioindicación para macroinvertebrados acuáticos de la sabana de Bogotá. Caldasia, 24: 135-156.

RIVERA, P., O. PARRA, M. GONZALEZ, V. DELLAROSA \& M. ORELLANA. 1982. Manual taxonómico del fitoplancton de aguas continentales. IV Bacillariopyaceae. Universidad de Concepción, Concepción, Chile.

RIVERA, C. A. \& J. CH. DONATO. 2008. Influencia de las variables hidrológicas y químicas sobre la diversidad de diatomeas bénticas. In: Ecología de un río de montaña de los Andes Colombianos (Río Tota, Boyacá). J. Ch. Donato (ed.): 83-101. Universidad Nacional de Colombia, Bogotá, Colombia.

ROLDÁN, G. 2003. Bioindicación de la calidad del agua en Colombia. Uso del método BMWP/Col. Universidad de Antioquia, Medellín, Colombia.

SALOMONI, S. E., O. ROCHA, V. L. CALLEGARO \& E. A LOBO. 2006. Epilithic diatoms as indicators of water quality in the Gravataí River, Rio Grande do Sul, Brazil. Hydrobiologia, 559: 233 246.

SOLAK, C. N. \& E. ÀCS. 2011. Water quality monitoring in European and Turkish rivers using diatoms. Turkish Journal of Fisheries and Aquatic Sciences, 11: 329-337.

STEVENSON, R. J. \& L. BAHLS. 1999. Periphyton protocols. In: Rapid bioassessment protocols for use in wadeable streams and rivers. Periphyton, benthic macroinvertebrates and fish. M.T. Barbour, J. Gerritsen, B.D. Snyder \& J. B. Stribling (eds.): 6-23. Environmental Protection Agency, Washington, USA.

STOERMER, E. \& J. SMOL. 2004. The diatoms, applications for the environmental and earth sciences. Cambridge University Press, Cambridge, United Kingdom.

VAN DER HAMMEN, T., F. G. STILES, L. ROSSELLI, M. L. CHISACÁ, G. CAMARGO, G. GUILLOT, Y. USECHE \& D. RIVERA. 2008. Protocolo de recuperación y rehabilitación ecológica de humedales en centros urbanos. Secretaría Distrital de Ambiente, Bogotá, Colombia.

VÁSQUEZ, C., A. ARIZA \& G. PINILLA. 2006. Descripción del estado trófico de diez humedales del Altiplano Cundiboyacense. Universitas Scientiarum, 11: 61-75.

VIS, C., C. HUDON, A. CATTANCO \& B. PINELALLOUL. 1998. Periphyton as an indicador of water quality in the St Lawrence River (Québec, Canada). Environmental Pollution, 101: 13-24.

WALKER, C. \& Y. PAN. 2006. Using diatom assemblages to assess urban stream conditions. Hydrobiologia, 561: 179-189.

WALSH, G. \& V. WEPENER. 2009. The influence of land use on water quality and diatom community structures in urban and agriculturally stressed rivers. Water South Africa, 35: 579-594.

WANG, Y., J. STEVENSON, R. SWEETS \& J. DIFRANCO. 2006. Developing and testing diatom indicators for wetlands in the Casco Bay watershed, Maine, USA. Hydrobiologia, 561: 191-206.

WESTLAKE, D. F., J. KVT \& A. SZCZEPASKI. 1998. The production ecology of wetlands. Cambridge University Press, Cambridge, United Kingdom.

WU, J. T. \& L. T. KOW. 2002. Applicability of a generic index for diatom assemblages to monitor pollution in the tropical River Tsanwun, Taiwan. Journal of Applied Phycology, 14: 63-69. 